\title{
In vitro Studies on Branch Canker Pathogen (Macrophoma sp.) Infecting Tea
}

\author{
Mareeswaran J*, Nepolean P, Jayanthi R, Premkumar Samuel Asir R and Radhakrishnan B
}

Plant Pathology Division, UPASI Tea Research Institute, Valparai-642127 Coimbatore District, Tamil Nadu, India

\begin{abstract}
Branch canker is the main stem disease of Camellia sp. caused by Macrophoma sp. In this study, branch canker pathogen was isolated, bought to pure culture and maintained in potato dextrose agar medium (PDA). A total number of 150 bacterial and 40 fungal strains were isolated from different agro climatic zone of south India, which are region specific and native strains (resembling Pseudomonas spp. Bacillus spp. and Trichoderma spp.). Among the total number of bacterial and fungal isolates, 6 bacterial and 3 Trichoderma spp. Showed antagonistic effect against the branch canker pathogen. The study clearly indicates that Bacillus spp. Pseudomonas spp. followed by Trichoderma spp. showed higher antagonistic potential against the test pathogen. The study also includes that, the selected botanical fungicides, neem kernel extract, garlic extract, Aloe vera, Tulsi and Expel (Botanical fungicides) at different concentration were carried out against Macrophoma sp. Results showed that, commercially available botanical fungicide (Expel) is effective to control the growth of branch canker pathogen compare then other chemical and botanical fungicides. The commonly used fungicides in tea plantation such as Hexaconazole (Contof $5 \mathrm{E}$ ), Tebuconazole (Folicur) and Tridemorph (Calixin) were evaluated against Macrophoma sp. under in vitro conditions. The results indicated that Tebuconazole all the three concentrations at $1.78 \mathrm{ppm}$ was found to be the most effective in suppressing the growth of branch canker pathogen. The results concluded that biocontrol agents (Bacillus spp. Pseudomonas spp and Trichoderma spp.), botanical fungicide (Expel) and chemical fungicide (Tebuconazole) are very effective to control the branch canker pathogen under in vitro conditions.
\end{abstract}

Keywords: Biocontrol agents; Botanical and chemical fungicides; Camellia sp.; Macrophoma sp.

\section{Introduction}

Tea, an evergreen plant is one of the most popular, non-alcoholic beverages consumed by nearly half the world population. Tea is produced from the young shoots of the commercially cultivated tea plant (Camellia sp.). India is the one of the largest producer and consumer of tea in the world with an area of 5.75 lacks/ha under tea cultivation. Tea is attacked by number of pests and diseases which are the major limiting factors in crop productivity. The first comprehensive account on the pests and diseases of tea was presented by Watt [1]. Majority of tea pathogens are of fungal origin and more than 300 species of fungi are reported to affect different parts of the tea plant [2-4]. Mann and Hutchinson [5] recorded various diseases and that was substantiated by Petch [6]. Sarmah [7] described all parasitic and non-parasitic/ physiological diseases. Among the stem diseases of tea, branch canker caused by Macrophoma theicola is a predominant stem inhabiting fungal disease which has been reported from Ceylon. Branch canker, Macrophoma theicola occurs in drought susceptible areas where soil is poor. In Kangra valley, Himachal Pradesh this disease was observed after rainy season, whereas the occurrence of the disease was very rare in Darjeeling [7]. M. theicola has been observed to cause twig die-back of mature tea in Taiwan [8]. In general, tea bush affected by sun-scorch is prone to this disease. The diseased patches on the branches appear as slightly sunken lesions surrounded by a ring of callus growth [7]. The affected branches are killed slowly by the invading fungus until the disease spreads to the collar when upper portion of the plant dies. In mild infestations, the canker is callused over completely within a few months, but the fungus may renew its growth forming concentric cankers under adverse conditions. Fructifications are produced on the dead bark during wet weather conditions. To control the disease; the affected branches should be cut out to clean healthy wood. Plants should be protected from sun-scorch and pruning should be avoided during dry weather. The crop loss due to this disease depends upon pathogen and the geographical area [9]. In Taiwan, around $40 \%$ of the tea bushes were killed by twig dieback and in south-east Asian countries, root rot disease was responsible for major crop loss $[4,10]$. Low yield due to incidence of collar and branch canker caused by Phomposis theae and Macrophoma theicola was reported from central Africa [11]. It has been difficult to control branch canker as it grows with the saprophytic fungi on the plant stem. Being a related anamorph genera of Botryosphaeria along with Botryodiplodia, Diplodia, Fusicoccum, Lasiodiplodia, Macrophomposis and Sphaeropsis, it was difficult to separate it from others as its morphological features were poorly defined [12]. The present study involves the isolation, morphological identification and the effect of different chemical and botanical fungicides, bio-control agents on Macrophoma sp.

\section{Materials and Methods}

\section{Sample collection}

Survey was conducted in major tea growing areas of south India (The Anamallais, Central Tranvancore, High Range, Wayanad, Coonoor and Koppa) to collect soil samples in order to isolate biocontrol agents and branch canker fungal pathogens.

*Corresponding author: Mareeswaran J, Plant Pathology Division, UPASI Tea Research Institute, Valparai-642127 Coimbatore District, Tamil Nadu, India, Tel: +919489219641; E-mail: jmareeswaran11@gmail.com

Received April 29, 2015; Accepted July 09, 2015; Published July 16, 2015

Citation: Mareeswaran J, Nepolean P, Jayanthi R, Premkumar Samuel Asir R, Radhakrishnan B (2015) In vitro Studies on Branch Canker Pathogen (Macrophoma sp.) Infecting Tea. J Plant Pathol Microb 6: 284. doi:10.4172/2157-7471.1000284

Copyright: @ 2015 Mareeswaran J, et al. This is an open-access article distributed under the terms of the Creative Commons Attribution License, which permits unrestricted use, distribution, and reproduction in any medium, provided the original author and source are credited. 


\section{Isolation of branch canker pathogen}

The infected stem portions were collected. The samples were washed in distilled water and were cut into small piece. Surface sterilized with $0.1 \%$ mercuric chloride for few seconds followed by sterile distilled watering, 2-3 times. After surface sterilization the infected portions were blotted on sterile filter paper and then inoculated on water agar plates amended with streptomycin $(50 \mathrm{mg} / \mathrm{lit})$. Plates were incubated for 3 to 5 days. The grown mycelial tips from water agar plates were aseptically transferred to potato dextrose agar medium (PDA). Pure cultures were obtained from the primary plates by colonies initiated from single spores or from hyphal tips. Single-spore cultures were made by preparing a suspension of spores in distilled sterile water and spreading it over water agar plates. Single germinated spores were removed on a small amount of agar with a transfer needle to a PDA medium. Distinct hyphal tips were cut from the well grown water agar plate and then sub-cultured repeatedly on PDA to obtain pure culture of the fungus.

\section{Isolation of bio-control agents from soil}

Soil samples at 0"- 9" depth were collected from three tea growing districts, High range Munnar, Central Travancore, Koppa and The Annamallais for isolation of biocontrol agents (Trichoderma spp. Bacillus spp. and Pseudomonas spp.). The Biocontrol agents were isolated by standard serial dilution plating techniques, sub cultured, brought to purity and stored in slants at $4^{\circ} \mathrm{C}$. The cultures were identified using standard bacteriological techniques.

\section{Screening for antagonism}

The isolated bacterial and fungal strains (Trichoderma spp. Bacillus spp. and Pseudomonas spp.) were screened for their antagonistic potential against the pathogen, following dual culture technique [13]. The mycelial plug of four day old, actively growing Macrophoma sp. was ground and spread uniformly on PDA medium plate with the help of a sterilized spatula. These plates were then spot inoculated within $24 \mathrm{~h}$ culture of isolated bacterial strains. Plates were incubated at $30 \pm$ $2{ }^{\circ} \mathrm{C}$ for 3-5 days. The antagonism was graded by measuring the zone of inhibition produced around the bacterial strains. The grading was given as (-) no antagonism, $(+)$ those showing inhibition zone of $<0.5$ $\mathrm{cm},(++)$ with $0.5 \mathrm{~cm}$ to $1 \mathrm{~cm}$ and $(+++)$ those with $>1.0 \mathrm{~cm}$. In the case of Trichoderma, in vitro screening was done by placing a mycelial plug of 4 days old culture of both pathogens and the antagonist. Time for the first contact between the antagonist and the pathogen and the advancement of the antagonist on the pathogen colony was noted and the efficient strains were short listed. A control plate was maintained for comparison. Radial growth of the pathogenic fungi was measured after comparison with control. Percent inhibition was calculated by the formula given by Bell et al. [14]

\section{Compatibility of pathogen against chemical fungicides}

Three systemic fungicides, hexaconazole (Contof 5E), tebuconazole (Folicur) and tridemorph (Calixin) which are commercially being used in the tea fields for the control of various fungal pathogens were selected for the compatibility study of the branch canker pathogen. Three dosages of the systemic chemical fungicide were tested. RDrecommended dosage (3.57 ppm), LR- lower recommended dosage $(1.78 \mathrm{ppm})$ and HR- higher recommended dosage $(5.35 \mathrm{ppm})$. These dosages were mixed with PDA and poured in sterile petri plates and allowed to solidify. Small blocks of the pure culture of the pathogen were cut using sterile cork borer $(7 \mathrm{~mm})$ and inoculated onto the solid medium. A control plate, devoid of the chemical fungicide was made as reference. The growth of the pathogen was observed for 10 days $\left(3^{\text {rd }}\right.$, $5^{\text {th }}, 7^{\text {th }}$ and $10^{\text {th }}$ days) and recorded.

\section{Compatibility of pathogen towards botanical fungicides}

Neem kernel extract: Dry neem seeds (approximately $100 \mathrm{~g}$ ) were ground using a mortar and pestle. The powder was tied in a sterile muslin cloth and soaked in $250 \mathrm{ml}$ sterile distilled water and left to stand overnight at room temperature. The extract was filtered using Whatmann filter paper No 1 . The filtrate was added to the PDA medium at different concentrations $(5 \%, 7.5 \%$ and $10 \%)$ to find out the effective dosage at which the pathogen cannot survive. The plates along with the extract, at various doses were inoculated by placing small block of the pure culture $(7 \mathrm{~mm})$. A control plate devoid of fungicide was maintained as the reference. The growth is observed for 10 days (at $3^{\text {rd }}, 5^{\text {th }}, 7^{\text {th }}$ and $10^{\text {th }}$ days) measured and recorded.

Garlic: $30 \mathrm{~g}$ of garlic was made to paste using mortar and pestle and mixed with $30 \mathrm{ml}$ of sterile distilled water. The extract was filtered using muslin cloth and the extract was added to the PDA medium at different concentrations $(1 \%, 2.5 \%$ and $5 \%)$ to find the percent inhibition at various dosage of garlic extract. The plates were inoculated the growth was measured and recorded as mentioned as earlier for neem kernel extract.

Tulsi: Tulsi leaves were cleaned with sterile distilled water and ground with $5 \mathrm{ml}$ of $95 \%$ ethanol using mortar and pestle. The ground paste was centrifuged at $5000 \mathrm{rpm}$ for $5 \mathrm{~min}$. The collected extract was used to prepare the disc.

Disc preparation: Discs were prepared with Whatmann No. 1 filter paper. The extract was added to $95 \%$ ethanol at various concentrations $(5 \%, 7.5 \%$ and $10 \%)$ and the prepared discs were immersed in it. The control discs were prepared by soaking the discs to $95 \%$ ethanol. The discs were kept in hot air oven at $45^{\circ} \mathrm{C}$ and left overnight to dry. The PDA plates were swabbed with the pure culture over the entire surface of the plate. This procedure was repeated twice and the plate was rotated $60^{\circ}$ each time to ensure an even distribution of the culture. The appropriate discs were placed (with plant extracts) evenly (no closer than $24 \mathrm{~mm}$ from centre to centre) on the surface of the agar plate either by using sterile forceps or the dispensing apparatus. After 7 days of incubation, each plate was examined and measured for the diameters of the zones of complete inhibition. The zones were measured to the nearest mm using a ruler.

Aloe vera: Gel portion of the leaf was separated using a sterile blade and ground using a mortar and pestle. The ground gel was filtered and the extract was collected. The collected extract was mixed up to $95 \%$ ethanol at various concentrations $(5 \%, 7.5 \%, 10 \%$ and $100 \%)$. The control discs were prepared using in 95\% ethanol and dried in hot air oven at $45^{\circ} \mathrm{C}$ overnight. The disc preparation and the procedure were same as that of tulsi.

Expel: The commercially available botanical fungicide Expel which is being widely used in the tea field was evaluated at low dose- $1.5 \mathrm{ppm}$, recommended dose- $3 \mathrm{ppm}$ and high dose- $4.5 \mathrm{ppm}$. The procedure was same as that of chemical fungicide method.

\section{Results and Discussion}

Survey was conducted in major tea growing areas of south India to collect the soil samples and disease specimens to isolate bio-control agents and branch canker fungal pathogen. A total of four branch canker pathogen and biocontrol were isolated from different tea growing district like the Anamallais (MT APF1), Central Tranvancore 
(MT HE 02), Coonoor (MT C2 03) and Koppa (MT KH 04) also specific same areas (The Anamallais - 2 Bacillus spp. and 2 - Trichoderma spp. Central Travancore - 1 Bacillus sp., Koppa - 2 Pseudomonas spp. and The Nilgiris - 1 Pseudomonas sp and 1- Trichoderma sp.) were showed bacterial and fungal biocontrol agents. The branch canker pathogen was morphologically, spore characteristically identified used as standard reference book image Petch [6] and confirmed as Macrophoma sp (Figure 1). A total number of 150 bacterial and 40 fungal isolate (resembling Pseudomonas spp. Bacillus spp. and Trichoderma spp.), were isolated and screened six bacterial and three Trichoderma spp. showed higher antagonistic effect against branch canker pathogen (Table 1). The antagonism was graded by recording the zone of inhibition produced around the bacterial strains. From this study it was concluded that Bacillus spp. Pseudomonas spp. followed by Trichoderma spp. were more inhibitory effect against branch canker pathogen (Figures 2 and 3). Three fungicides, hexaconazole (Contof 5E), tebuconazole (Folicur) and tridemorph (Calixin) were evaluated against Macrophoma sp. under in vitro condition. The results indicated that, Tebuconazole all the three concentrations at $1.78 \mathrm{ppm}$ was found to be the most effective in suppressing the growth of pathogen followed by hexaconazole and tridemorph. Hexaconazole at $1.78 \mathrm{ppm}$ and tridemorph at $3.57 \mathrm{ppm}$ were found to be optimum for the control of pathogen growth (Table 2). The study revealed that Tebuconazole completely inhibited the growth of branch canker pathogen compared

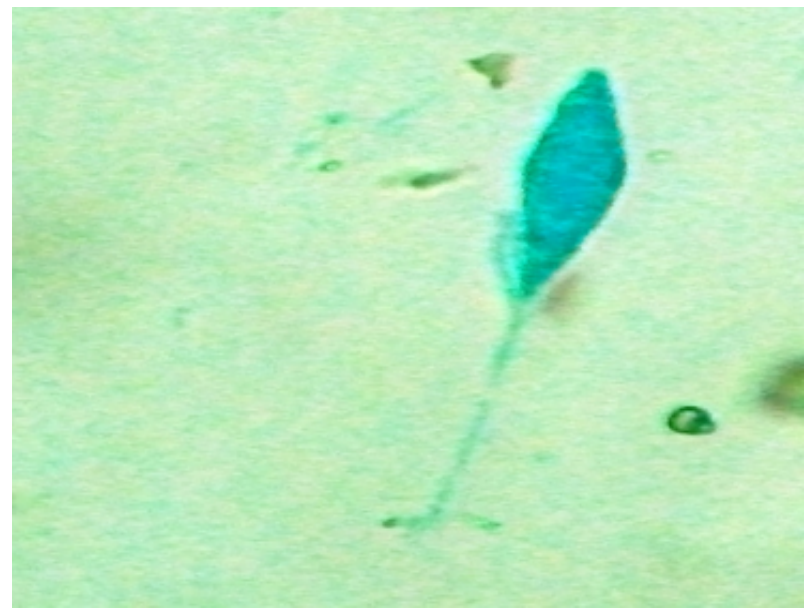

Figure 1: Microscopic view of Macrophoma sp. A single pycno spore is magnified through $40 \mathrm{x}$ which was isolated from Branch canker infected stem obtained from the Nilgiris.

\begin{tabular}{|c|c|c|c|c|}
\hline \multirow[b]{2}{*}{$\begin{array}{l}\text { Tea growing } \\
\text { districts }\end{array}$} & \multirow[b]{2}{*}{$\begin{array}{l}\text { Number of } \\
\text { bacterial } \\
\text { isolates }\end{array}$} & \multirow[b]{2}{*}{$\begin{array}{l}\text { Number of } \\
\text { Trichoderma } \\
\text { spp. isolates }\end{array}$} & \multicolumn{2}{|c|}{$\begin{array}{l}\text { No. of antagonist against } \\
\text { Macrophoma sp. }\end{array}$} \\
\hline & & & $\begin{array}{l}\text { Bacterial strains } \\
\text { (Bacillus spp. and } \\
\text { Pseudomonas } \\
\text { spp.) }\end{array}$ & $\begin{array}{l}\text { Trichoderma } \\
\text { spp. }\end{array}$ \\
\hline $\begin{array}{l}\text { 1. The } \\
\text { Anamallais }\end{array}$ & 25 & 15 & $2(2 \mathrm{~cm})^{*}$ & 2 \\
\hline 2. The Nilgiris & 50 & 5 & $1(>1 \mathrm{~cm})$ & 1 \\
\hline $\begin{array}{l}\text { 3. Central } \\
\text { Travancore }\end{array}$ & 50 & 15 & $1(>1 \mathrm{~cm})$ & - \\
\hline 4. Корра & 25 & 5 & $2(1-2 \mathrm{~cm})^{*}$ & - \\
\hline Total & 150 & 40 & 6 & 3 \\
\hline
\end{tabular}

Table 1: List of biocontrol bacterial and fungal strains isolated from various tea growing areas *Values in parentheses indicate inhibition zone produced by bacterial antagonist.

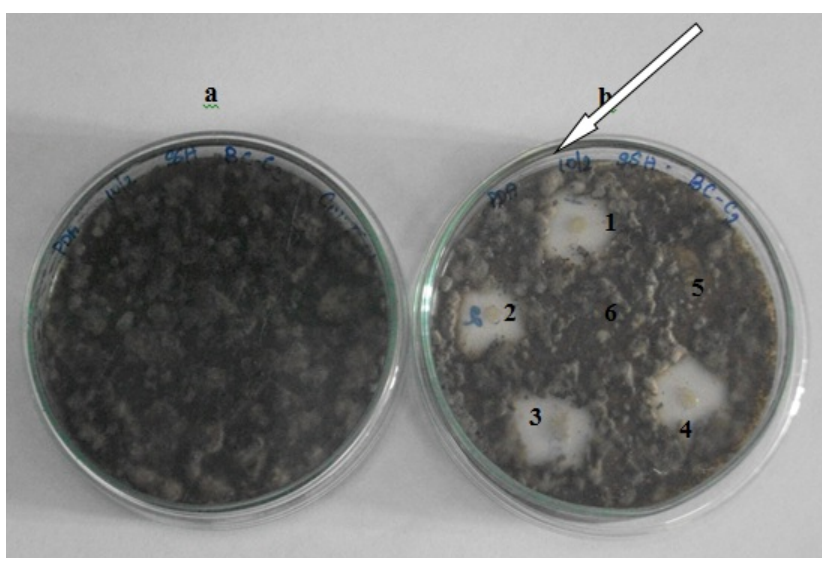

Figure 2: Control plate (a) Macrophoma sp. spreaded PDA plate is free from bacterial antagonist and (b) Bacillus spp. and Pseudomonas spp. inhibited the growth of Macrophoma sp. (Arrow indicates the zone of inhibition between fungal pathogen \& bacterial antagonist).

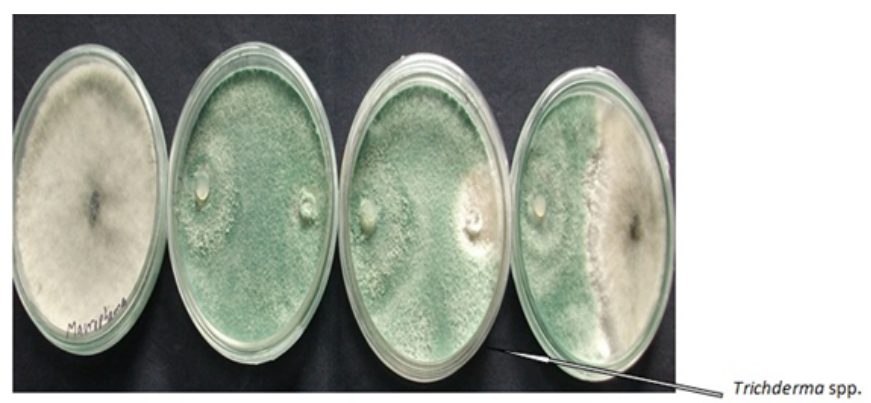

Figure 3: Trichderma spp. against Macrophoma sp. pathogen.

\begin{tabular}{|c|c|c|c|c|}
\hline \multicolumn{2}{|c|}{ Fungicides } & $\begin{array}{c}\text { Fungicide } \\
\text { concentration } \\
\text { (ppm) }\end{array}$ & $\begin{array}{c}\text { Mean radial } \\
\text { growth (cm) }\end{array}$ & $\begin{array}{c}\text { \% inhibition of } \\
\text { growth (\%) }\end{array}$ \\
\hline \multirow{3}{*}{ 1. Hexaconazole } & RD & 3.57 & 0.00 & 100 \\
\cline { 2 - 5 } & LR & 1.78 & 7.58 & 75.8 \\
\cline { 2 - 5 } & HR & 5.35 & 0.00 & 100 \\
\hline \multirow{3}{*}{ 2.Tebuconazole } & RD & 3.57 & 0.00 & 100 \\
\cline { 2 - 5 } & LR & 1.78 & 0.00 & 100 \\
\cline { 2 - 5 } & HR & 5.35 & 0.00 & 100 \\
\hline \multirow{3}{*}{3. Tridemorph } & RD & 3.57 & 0.00 & 100 \\
\cline { 2 - 5 } & LR & 1.78 & 0.62 & 6.24 \\
\cline { 2 - 5 } & HR & 5.35 & 0.00 & 100 \\
\hline Control plate & UT & - & 9.00 & 0 \\
\hline
\end{tabular}

Table 2: In vitro efficacy of different fungicides on Macrophoma sp. *On 10th day. Values in the parentheses indicate percent inhibition of the pathogen RD: Recommended Dosage; LR: Lower Recommended Dosage; HR: Higher Recommended Dosage and UT: Untreated control.

to that other two fungicides. There was absolutely no growth in the fungicide amended plates even at a lower concentration (Figure 4). Among the botanical fungicides tested, expel showed the highest percentage of inhibition against Macrophoma sp under in vitro condition (Table 3). While Tulsi, Neem kernel, Aloe vera and garlic extract had no growth effect of Macrophoma sp. (Table 4). In this study, commercially available botanical fungicide (Expel) is effective to control the branch canker disease without any residual effect and maintaining the soil structure, bush health when compared to the 


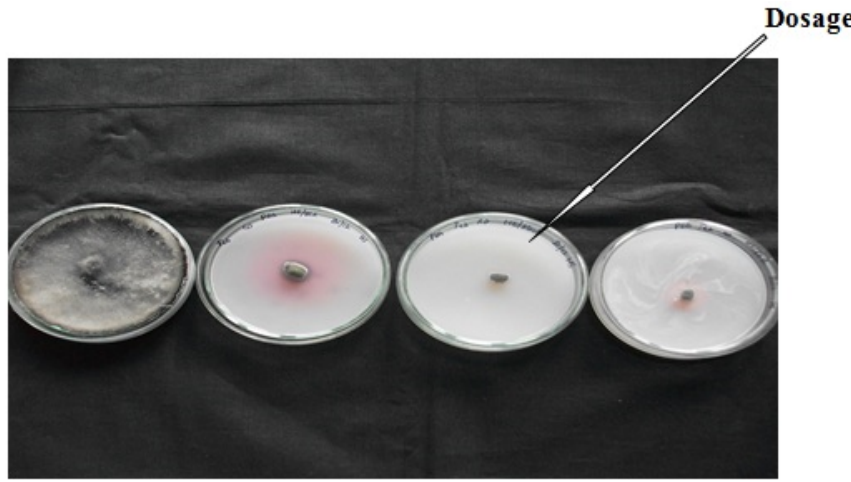

Figure 4: Tebuconozole inhibitied the growth of Macrophoma sp. with three different concentration. UT-Untreated control, LD: Lower Recommended Dosage, RD: Recommended Dosage, HR: Higher Recommended Dosage.

\begin{tabular}{|c|c|c|c|c|c|c|c|c|c|c|c|c|}
\hline Isolates & \multicolumn{4}{|c|}{$3^{\text {rd }}$ day } & \multicolumn{4}{c|}{$5^{\text {th }}$ day } & \multicolumn{3}{c|}{$1^{\text {th }}$ day } \\
\hline Dosage & U & LD & RD & HD & U & LD & RD & HD & U & LD & RD & HD \\
\hline MT APF1 & 8.50 & - & - & - & 9.00 & - & - & - & 9.00 & 74.4 & - & - \\
\hline MT HE 02 & 9.00 & 85.0 & 86.6 & 87.7 & 9.00 & 64.4 & 67.7 & 85.0 & 9.00 & 60.3 & 62.3 & 76.1 \\
\hline MT C2 03 & 3.50 & 48.2 & 54.9 & - & 4.55 & 47.4 & 54.0 & 69.2 & 8.10 & 40.0 & 52.8 & 65.8 \\
\hline MT KH 04 & 9.00 & 86.6 & 88.8 & 89.9 & 9.00 & 83.3 & 87.7 & 87.7 & 9.00 & 75.4 & 82.4 & 84.4 \\
\hline
\end{tabular}

Table 3: Effect of botanical fungicide (Expel) on in vitro growth of Macrophoma spp. Means of 5 replicates and four different isolates. *(-) no growth *the values indicate percentage inhibition *the values of untreated are indicated in centimeters. U: Untreated, LD: Low Dose, RD: Recommended Dose and HD: High Dose.

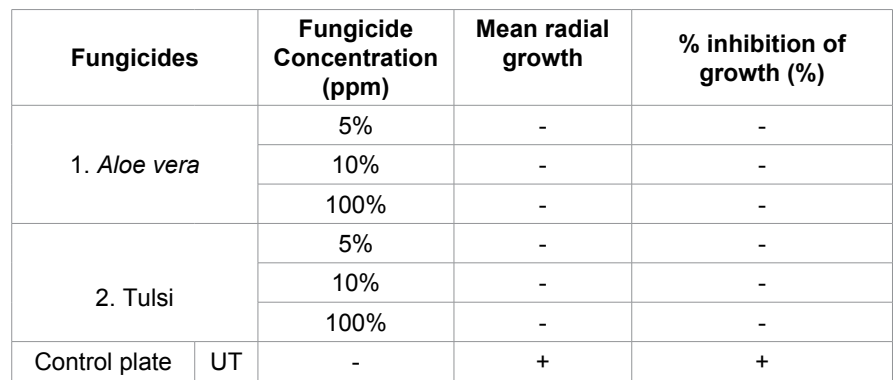

Table 4: In vitro efficacy of different botanical fungicides on Macrophoma spp. (Means of 5 replicates and 4 different isolates). Garlic and Neem Kernel were noticed same results (-) samples showed no growth. *On 10th day. Values in the parentheses indicate percent inhibition of the pathogen. (+) samples showed growth (-) samples showed no growth.

other chemical fungicides. Same result recorded with Nepolean et al. [15] expel botanical fungicide and bacterial biocontrol agents were showed good results against wood rot pathogen. Long term application of PGPR resulted in reduced disease incidence in field grown tea plants. When fungicide or biocontrol agents were incorporated their efficiency in controlling the disease was also improved. Continuous application of PGPR helped the plants to build up natural resistance to the disease. Silva et al. [16] reported reduction of fungicide application number of rounds (50\%) in tomato plants treated with Bacillus cereus, which provided protection against multiple diseases. In recent studies on antagonistic potential of biocontrol agents against tea pathogens, Hypoxylon sp. and Pestalotiopsis sp. were tested under in vitro level and the results indicated that Pseudomonas sp. and Trichoderma sp. exhibited superior antagonistic potential against the grey blight and wood rot pathogens [17]. The study clearly indicated that each 3 strains of Bacillus and Pseudomonas that showed higher antagonism against branch canker pathogen. Trichoderma spp. isolated from such a region showed effective antagonism against Macrophoma sp. and Bacillus spp. provided excellent control of the branch canker disease. Similar results were reported by Nandakumar et al. [18], Vivekananthan et al. [19], Vidhyasekaran and Muthamilan [20] and Ramamoorthy et al. [21], for the control of various fungal pathogens. When groundnut plants were sprayed with $P$. fluorescencs, increased activity of PAL was observed and correlated with the lesser disease incidence [22]. In the present study, Bacillus spp. and Pseudomonas spp. followed by Trichoderma spp. showed more inhibitory effect against Macrophoma sp. under in vitro condition. Standard fungicides and biological control agents provided satisfactory control of the disease under the field conditions without any residual effects on tea. In this result accordance with Premkumar and Baby [23] have published the latest recommendations on the control of blister blight and grey blight in tea and also Karthika and Muraleedharan [24] supported that, fungicides residues were lost during the shoot expansion time and the $10^{\text {th }}$ day, the level of residues on tea shoots are definitely lower than the limits of residue effect. Hence upon the climatic factor, i.e., due to such as mainly growth dilution, rainfall elution, thermal degradation and photodegradation. Both the fungal and bacterial biocontrol agents provided superior control for the integrated management of grey blight disease. Jo and willson [25] found that the exogenous application sof carbon and nitrogen sources increased the population of biocontrol agent, $P$. syringae in the phyllosphere and increased the biocontrol efficacy. The present study revived that the potential of the selected chemical fungicides (hexaconazole, tebuconazole and tridemorph). To sum up, the present investigation proved beyond doubt that various botanical fungicides like (Expel) neem kernel extract, garlic extract, aloe vera, tulsi and expel were experimented. It was found that expel showed the highest percentage of inhibition against Macrophoma sp. while Tulsi, Neem kernel, Garlic extract, and Aloe vera had no growth effect of test pathogen.

\section{Conclusion}

The study indicated that biocontrol agents (Bacillus spp. Pseudomonas spp. and Trichoderma spp.), botanical fungicide (Expel) and chemical fungicide (Tebuconazole) are very effective to control the branch canker pathogen under in vitro conditions. There was absolutely no growth in the fungicide amended plates even at a lower concentration. From this study, it was critically evaluated that Bacillus spp. and Pseudomonas spp. followed by Trichoderma spp. botanical fungicide (Expel) and chemical fungicide (tebuconazole) strengthens the integrated disease management of branch canker disease in tea.

\section{Acknowledgements}

The authors are thankful to UPASI Tea Research Institute, Valparai, Coimbatore dist. for their constant encouragement. We wish to extend our heartfelt thanks to Tea Board of India, Kolkata, for the financial support.

\section{References}

1. Watt $\mathrm{G}$ (1898) The pests and blights of tea plants. Cal. pp. 443-459.

2. Agnihothrudu V (1964) A world list of fungi reported on tea (Camellia spp.). J Madras Univ 34: 155-271.

3. Agnihothrudu V (1967) Some probable traumatic parasites on tea and rubber in southern India. Indian Phytopath 20: 196-198.

4. Chen ZM, Chen XF (1990) The diagnosis of tea disease and their control. Shanghai Sci. And Tech. Publ. Shanghai, China p. 275.

5. Mann HH, Hutchinson $\mathrm{CH}$ (1904) Red rust, (2ndedn) I.T.A. Bull. p. 26

6. Petch T (1923) Diseases of the tea bush. Macmillan and Co. Ltd, London. p. 220 
Citation: Mareeswaran J, Nepolean P, Jayanthi R, Premkumar Samuel Asir R, Radhakrishnan B (2015) In vitro Studies on Branch Canker Pathogen (Macrophoma sp.) Infecting Tea. J Plant Pathol Microb 6: 284. doi:10.4172/2157-7471.1000284

7. Sarmah KC (1960) Diseases of tea and associated crops in north east India Indian Tea Association, Scientific Department, Tocklai Experimental Station Memorandum No 26, p. 68

8. Arulpragasam PV (1992) Disease control in Asia, In: Wilson KC, Clifford MN (eds) Tea cultivation to consumption. Chapman and Hall, London pp. 353-373.

9. Haira GN (2001) Tea cultivation, comprehensive treatise. International book Distributing Company, Lucknow. p. 518.

10. Muraleedharan N, Chen ZM (1997) Pests and diseases of tea and their management. Journal Plant Crops 25: 15-43.

11. Rattan PS, Sobrak A (1976) Incidence of Phomposis stem and branch canker Annual report. The Tea research Foundation of Central Africa. Malawi.

12. Crous PW, Palm ME (1999) Reassessment of the anamorph genera Botryodipoldia, Dothiorella and Fusicoccum. Sydowia 52: 167-175.

13. Rajendiran R, Jegadeeshkumar D, Sureshkumar BT, Nisha T (2010) In vitro assessment of antagonistic activity of Trichoderma viride against post harvest pathogens. Journal of Agric Technol 6: 31-35.

14. Bell DK, Wells HD, Markham CR (1982) In vitro antagonism of Trichoderma Species against six fungal plant pathogens. Phytopathol 72: 379-382.

15. Nepolean P, Balamurugan A, Jayanthi R, Mareeswaran J, Premkumar R (2014) Bio efficacy of certain chemical and biofungicides against wood rot pathogen. Journal of Plantation Crops 42: 341-347.

16. Silva HSA, Romeiro RS, Carrer Filho R, Pereora JLA, Mounteer A (2004) Induction of systemic resistance by Bacillus cereus against tomato foliar diseases under field conditions. J Phytopathology 152: 371-375.

17. Vidhya Pallavi R, Nepolean P, Balamurugan A, Pradeepa N, Kuberan T, et al.
(2010) In-vitro studies on antagonistic potential of biocontrol agents against tea pathogens, Hypoxylon sp. and Pestalotiopsis sp. Rubber Research Institute of India, Kottayam. pp. 172-173.

18. Nandakumar R, Babu S, Viswanathana R, Raguchander T, Samiyappan R (2001) Induction of systemic resistance in rice against sheath blight disease by plant growth promoting rhizobacteria. Soil Biol Biochem 33: 603-612.

19. Vivekananthan R, Ravi M, Ramanathan A, Samiyappan R (2004) Lytic enzymes induced by Pseudomonas fluorescens and other biocontrol organisms mediate defence against the anthracnose pathogen in mango. World J. Microbiol. Biotechnol 20: 235-244.

20. Vidhyasekaran R, Muthamilan M (1995) Development of formulations of Pseudomonas fluorescens for control of chickpea wilt. Plant Dis 79: 782-786.

21. Ramamoorthy V, Viswanthan R, Raguchander T, Prakasam V, Samiyappan $R$ (2001) Induction of systemic resistance by plant growth promoting rhizobacteria in crop plants against pest and diseases. Crop Prot 20: 1-11.

22. Meena B, Radhajeyalakshmi R, Marimuthu T, Vidhyasekaran $P$, Doraisamy $S$, et al. (2000) Induction of Pathogenesis related proteins, phenolics and phenylalanine ammonia lyase in groundnut by Pseudomonas fluorescens. J Plant Dis Prot 107: 514-527.

23. Premkumar R, Baby UI (2005) Blister blight control a review of current recommendations. Journal of Plantation Crops 101: 26-34.

24. Karthika C, Muraleedharan NN (2009) Contribution of leaf growth on the disappearance of fungicides used on tea under South Indian agroclimatic conditions. J Zhejiang Univ Sci B 10: 422-426.

25. Ji P, Wilson M (2003) Enhancement of population size of a biological contro agent and efficacy in control of bacterial speck of tomato through salicylate and ammonium sulfate amendments. Appl Environ Microbiol 69: 1290-1294. 